\title{
Photoelectrochemical Studies at CdS/PTTh Nanoparticles Interfaces
}

\author{
Kasem K. Kasem*, Nida Zia
}

School of Sciences, Indiana University, Bloomington, USA.

Email: *kkasem@iuk.edu

Received July $13^{\text {th }}, 2012$; revised August $15^{\text {th }}, 2012$; accepted September $16^{\text {th }}, 2012$

\begin{abstract}
Photo-activities at Inorganic/Organic/Interfaces (IOI) consisting of CdS/Polyterthiophine (PTTh) assemblies were investigated in nanoparticle suspension and in thin solid film forms. The effects PTTh modifier cause on the photoelectrochemical behavior of the IOI were investigated using $\left[\mathrm{Fe}(\mathrm{CN})_{6}\right]^{4-}$ as photoactive hydrated electron donor agent. Results show that the adsorption process of $\left[\mathrm{Fe}(\mathrm{CN})_{6}\right]^{3-}$ (photolysis product) control the photoactivity outcome of IOI assemblies. CdS/PTTh shows lower heterogeneous photochemical response than native CdS. Native CdS amorphous nanoparticles adsorb more $\left[\mathrm{Fe}(\mathrm{CN})_{6}\right]^{3-}$ with very steady adsorption/desorption process than the modified ones. The interface activities were explained by analyzing the IOI junctions' characteristics, such as electron affinity, work function and hole/electrons barrier heights. The aqueous nano-systems retained moderate stability as indicated by the reproducibility of their photocatalytic activities. Both $\left[\mathrm{Fe}(\mathrm{CN})_{6}\right]^{4-}$ and PTTh contributed to the stability of native CdS surfaces.
\end{abstract}

Keywords: Poly-Terthiophine; Nanoparticles; Photolysis; Inorganic/Organic/Interface; CdS

\section{Introduction}

Modification of native semiconductor (SC) surfaces can cause noticeable changes of the behavior of the modified surfaces. In general, unlike doping, surface modification can affect the band bending and the charge densities at the modified interfaces. Assemblies consisting of inorganicorganic interfaces (IOI) and organic-inorganic interfaces (OII) possessing great photo-conversion efficiency and high photo-corrosion resistance have been the focus of attention of several investigations in the field of solar energy. A number of semiconductor systems in the form of thin film-electrodes or colloidal systems which might be used in solid or liquid photovoltaic cells have been investigated [1-10], including metal chalcogenides modified with poly aniline, poly-payroll, or other organic semiconductors to name but few [11-19]. But in these studies, low conversion efficiencies were reported. Ordered assemblies of narrow band gap (Eg) semiconductor nanostructures can be convenient systems to harvest visible light energy. Metal/chalcogenides/oxide semiconductors absorb only solar radiation that matches their band gaps. However, the range of the radiation spectrum can be widened if the surfaces of the semiconductor surface are modified with agent/s that can absorb or become excited by greater radiation energies, such as UV. Some

"Corresponding author. conjugated organic semiconductors absorb UV radiations and then re-emit radiation at longer wave lengths. If an inorganic semiconductor absorbs photons emitted from adsorbed organic agent, then this IOI assembly produces a widened solar radiation absorption range.

Modified CdS with poly RuvbPy, was investigated $[20,21]$ in the form of thin solid films.

Thin films generally offer very limited surface area, which consequently limits the amount of radiation that can be absorbed. The poor resistance to photo corrosion reported $[22,23]$ adds another disadvantage of using macrostructures such as thin sold films.

The interest in the hybrid Inorganic/Organic interfaces or (IOI) was driven by the search for improving the solar energy conversion efficiencies in photovoltaic assemblies. The hetero-junction at the IOI assembly can affect its chemical, electrochemical, optical, magnetic and mechanical properties. Creating effective IOI requires energy coordination between the organic and inorganic interfaces for efficient charge transfer and separation as in $\mathrm{p}-\mathrm{n}$ junction-type assemblies. Information about physiccal quantities such as electronegativity (EA), Electron affinity (EA), work function $(\boldsymbol{\Phi})$, barrier height $(\boldsymbol{\varphi})$ and band gap (Eg) for components of the IOI will help achieving $\mathrm{p}-\mathrm{n}$ junction assemblies. In this paper, we record a creation of a hybrid IOI assembly of CdS and PTTh, and the effects that PTTh has as surface modifiers 
on the photo-activities of CdS nanoparticles during the photolysis process were investigated. The CdS/PTTh assemblies were either in forms of aqueous suspensions of these SC, or in the form of thin solid films. Photoactive buffered solution of $\left[\mathrm{Fe}(\mathrm{CN})_{6}\right]^{4-}$ as an electron donor was used to track the expected changes at the studied IOI assemblies. The recorded photocurrent produced during the photolysis process will be used in drawing conclusions about the type of effect/s and its magnitude that may be caused by these modifiers. Special emphasis will be given to the effectiveness in harvesting UV-VIS radiation when these $\mathrm{CdS}$ particles are integrated into IOI.

\section{Experimental}

\subsection{Reagents}

All the reagents were of analytical grade. All of the solutions were prepared using de-ionized water, unless otherwise stated. CdS/, CdS/PTTh were either in nanoparticles form or thin solid films.

\subsection{Preparation of $\mathrm{CdS} / \mathrm{PTTh} / \mathrm{Interface}$}

1) Colloidal suspensions of $\mathrm{CdS} / \mathrm{PTTh}$ interface were prepared following procedures similar to those previously reported $[24,25]$. Briefly, the photopolymerization syntheses of $\mathrm{CdS} / \mathrm{PTTh}$ were carried out in an open Petri dish, where a suspension of $\mathrm{CdS}$ in a solution of terthiophine in $1.0 \mathrm{M}$ of $\mathrm{HNO}_{3}$ was irradiated with UV-VIS source overnight. The reaction temperature was kept at around $30^{\circ} \mathrm{C}$, after which the solution was centrifuged and the precipitated material washed with water and acetonitrile until the remaining solution became clear.

2) Electrodeposition of thin solid films form: Suspensions of CdS nanoparticles and terthiophine monomer in acetonitrile solutions containing $0.2 \mathrm{M} \mathrm{LiClO}_{4}$ were used as electrodeposition bath. FTO (Fluorinated tin oxide, $1 \mathrm{~cm} \times 6 \mathrm{~cm}$ ), were used as substrate electrodes for the deposited $\mathrm{CdS} / \mathrm{PTTh} /$ interface film. The oxidative electropolymerization process took place by repetitive cycling of FTO potential between $-0.5 \mathrm{~V}$ to $1.60 \mathrm{~V}$ vs $\mathrm{Ag} / \mathrm{AgCl}$ electrode. Films generated in this way were very thin, smooth, and evenly spread over the surface, but also give small photo response.

3) Deposition of thin solid films: Electrodes of thin solid films of CdS particles modified with PTTh prepared as described in 1, were suspended in polyethylene oxide solution. The suspension was homogenously spread over an FTO slide $(12.5 \mathrm{~mm} \times 75 \mathrm{~mm})$ and dried at $120^{\circ} \mathrm{C}$ for 6 hours. The assembled electrode was transferred to a three electrode cell with $\mathrm{Ag} / \mathrm{AgCl}$ and $\mathrm{Pt}$ electrode as a reference and counter electrodes respectively in chosen buffer for electrolyte.

\subsection{Instrumentation}

All electrochemical experiments were carried out using a conventional three electrode cell consisting of Pt wire as a counter electrode, a $\mathrm{Ag} / \mathrm{AgCl}$ as a reference electrode, and Pt Gauze as an electron collector. A BAS $100 \mathrm{~W}$ electrochemical analyzer (Bioanalytical Co.) was used to perform the electrochemical studies. Steady state reflectance spectra were performed using Shimadzu UV-2101 PC. Irradiation was performed with a solar simulator 300 watt xenon lamp (Newport) with an IR filter.

\subsection{Fluorescence Lifetime Measurements}

Fluorescence lifetime measurements were performed using a Chronos (ISS, Champaign, IL) with a laser diode as the excitation source [26].

\subsection{Photolysis Cell}

The electrolysis cell was a one compartment Pyrex cell with a quartz window facing the irradiation source [27]. The working electrode, a $10.0 \mathrm{~cm}^{2}$ platinum gauze cylinder had a solution volume of $100 \mathrm{~mL}$. Suspensions were stirred with a magnetic stirrer during the measurements. A Ag/ $\mathrm{AgCl} / \mathrm{Cl}^{-}$reference electrode was also fitted into this compartment. A $10 \mathrm{~cm}^{2}$ platinum counter electrode was housed in a glass cylinder sealed in one end with a fine porosity glass frit.

Photolysis of $\left[\mathrm{Fe}(\mathrm{CN})_{6}\right]^{4-}$ will generate hydrated electrons and $\left[\mathrm{Fe}(\mathrm{CN})_{6}\right]^{3-}$. The potential of the working electrode was fixed at $100 \mathrm{mV}$ more negative than the reduction potential of $\left[\mathrm{Fe}(\mathrm{CN})_{6}\right]^{3-}$ to guarantee full reduction of ferricyanide. The current due to the reduction of $\left[\mathrm{Fe}(\mathrm{CN})_{6}\right]^{3-}$ collected by the working electrode during the photolysis process is a measure of photocurrent. Measured photocurrent was normalized considering two photons per one hydrogen molecule, and was used to calculate the number of moles of hydrogen generated per square meter per hour of illumination. The experimental work unless otherwise stated took place at room temperature $25^{\circ} \mathrm{C}$.

\section{Results and Discussion}

\subsection{Electrodeposition of Thin Solid Film}

Oxidative electropolymerization of terthiophine monomers took place by repetitive cycling of the FTO electrode potential between -0.5 to $1.5 \mathrm{~V}$ vs $\mathrm{Ag} / \mathrm{AgCl}$. The results are displayed in Figure 1. Cyclic voltammetry of formed polymer in supporting electrolyte only is similar to that displayed in Figure 1. It can be noticed that the both anodic and catholic peak current decreases by repetitive cycling of the potential. The value of $\Delta \mathrm{E}_{\mathrm{p}}$ is greater than that expected to be for surface wave. This 


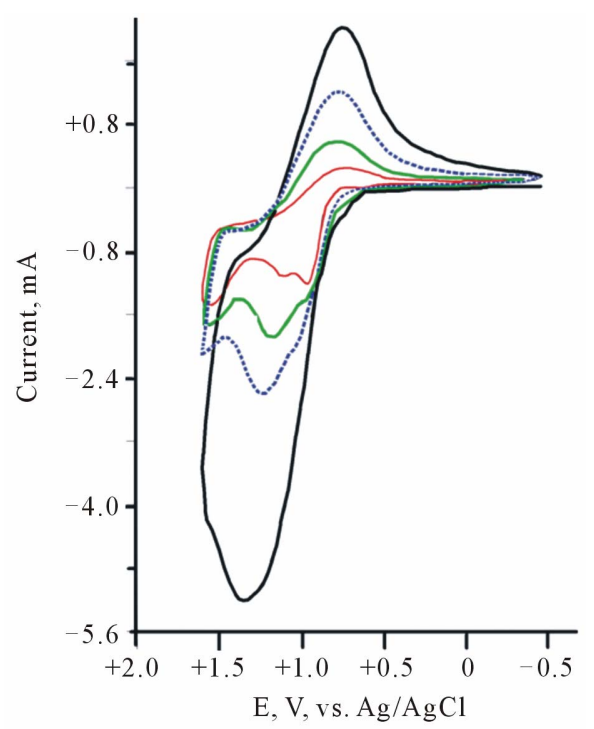

Figure 1. Repetitive CV of ITO electrode in suspension of CdS nanoparticles and $10 \mathrm{mMter}$-Thiophine monomer in acetonitrile solutions containing $0.2 \mathrm{M} \mathrm{LiClO}_{4}$. Scan rate 50 $\mathrm{mV} / \mathrm{sec}$.

can be attributed to the semiconducting nature of the polymer film. Furthermore, onset oxidation potential $\mathrm{E}_{\mathrm{ox}}^{\prime}$ of PTTh. can be detected at $1.20 \mathrm{~V}$ vs $\mathrm{Ag} / \mathrm{AgCl}$. This value will be used to calculate the Ionization potential of the PTTh.

\subsection{Absorption Spectra of PTTh Film}

Absorption spectra of PTTh thin films deposited over ITO are displayed in Figure 2. In this figure we can identify a broad absorption peak in the wavelength range of 430 to $490 \mathrm{~nm}$. This broad absorption peak corresponds to an $\mathrm{E}_{\mathrm{g}}$ range from 2.95 to $2.48 \mathrm{eV}$. This is also an indication of energy intervals with high density states that represent HOMO (higher occupied molecular orbitals) and LUMO (lower unoccupied molecular orbitals). The absorbed photons are consumed in generating charge carriers, probably by an extrinsic mechanism. The calculated molar absorptivity for this compound was found to be in the range of $10^{5} \mathrm{M}^{-1} \mathrm{~cm}^{-1}$. This value is consistent with the measured $2.88 \mathrm{~ns}$ as life time of terthiophine excited state.

\subsection{Energy Map of Poly Terthiophine}

In order to draw the energy map of PTTh, along with the band gap $\left(\mathrm{E}_{\mathrm{g}}\right)$, parameters such as IP and EA are required. Furthermore, these parameters are needed to explain the electrical and optical properties of the film. Relating electrochemical data, such as the onset oxidation potential $\left(\mathrm{E}_{\mathrm{ox}}^{\prime}\right)$, the onset reduction potential $\left(\mathrm{E}_{\mathrm{Red}}^{\prime}\right)$, and the band gap leads to an understanding of the integrated energy diagram of the film. Onset potentials can be esti-

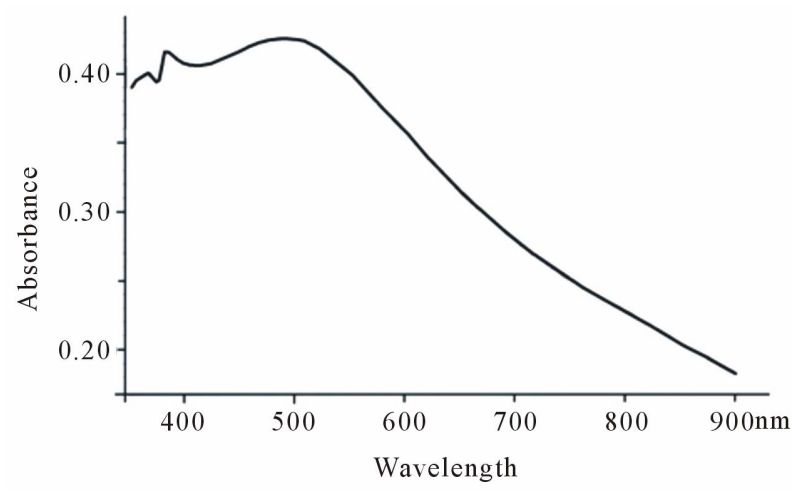

Figure 2. Absorption spectra of PTTh film of FTO.

mated from the intersection of the two tangents drawn at the rising oxidation current and the background current in the CV using the following formula [28]:

$$
\mathrm{E}_{\mathrm{ox}}=\mathrm{E}_{\mathrm{ox}}^{\prime}+\mathrm{E}_{\text {reference electrode }} \approx \mathrm{E}_{\mathrm{vac}}+4.6 \mathrm{eV}
$$

As $\mathrm{Ag} / \mathrm{AgCl}$ was used as a reference electrode $\left(\mathrm{E}^{0}=\right.$ $0.197 \mathrm{~V}$ vs NHE), and $\mathrm{E}_{\mathrm{vac}} \approx 0$, the above equation can be written as follows:

$$
\mathrm{IP}=\mathrm{E}_{\mathrm{ox}}^{\prime}+4.4 \mathrm{eV}
$$

Considering the energy gap between HOMO (valence band) and LUMO (conduction band) to be the band gap $\left(E_{g}\right)$, and the energy gap between the LUMO and vacuum level to be the electron affinity (EA), we can write the following equation:

$$
\mathrm{IP}=\mathrm{EA}+\mathrm{E}_{\mathrm{g}}
$$

Table 1 list of photo-electrochemical data for CdS and PTTh.

The reported EA of $3.12 \mathrm{eV}$ for PTTh that is lower than that of $\mathrm{CdS}(\mathrm{EA}=4.45 \mathrm{eV})$ reflecting an electron donor or a p-type semiconductor with $\varphi$ (hole barrier height) of $0.9 \mathrm{eV}$.

\subsection{Photoelectrochemical Behavior of CdS/PTTh Aqueous Suspensions}

\subsubsection{Theory}

Photolysis of $\left[\mathrm{Fe}(\mathrm{CN})_{6}\right]^{4-}$ generating hydrated electrons $\left(e_{a q_{-}}\right)$. These electrons can play an important role in photo-dissociation of water through these reactions:

$$
\begin{aligned}
& {\left[\mathrm{Fe}(\mathrm{CN})_{6}\right]^{4-}+h v=\left[\mathrm{Fe}(\mathrm{CN})_{6}\right]^{3-}+e_{a q-}} \\
& e_{a q-}+e_{a q-}=\mathrm{H}_{2}+2 \mathrm{OH}^{-}
\end{aligned}
$$

If the reaction in Equation 4 is reversed by reducing $\left[\mathrm{Fe}(\mathrm{CN})_{6}\right]^{3-}$ back to $\left[\mathrm{Fe}(\mathrm{CN})_{6}\right]^{4-}$, generation of hydrated electrons will continue. Reversing reaction 1 is possible by using a $\mathrm{SC}$ that emits electrons upon illumination according to the following reaction: 
Table 1. Photo-electrochemical data at CdS/PTThInterface.

\begin{tabular}{|c|c|c|}
\hline Property, eV & $\mathrm{CdS}$ & PTTh \\
\hline $\begin{array}{l}\text { Onset Oxidation potential } \\
\text { (vs, } \mathrm{Ag} / \mathrm{AgCl})\end{array}$ & & $1.2 \mathrm{~V}, \mathrm{vs} \mathrm{Ag} / \mathrm{AgCl}$ \\
\hline Measured band gap, Ea & 2.2 & 2.48 \\
\hline Ionization potential IP & & 5.6 \\
\hline Work function $\boldsymbol{\Phi}$ & 4.7 & \\
\hline Electron Affinity EA & 4.45 & 3.12 \\
\hline Holes' Barrier Height, $\boldsymbol{\varphi}_{h}$ at IOI* & & 0.9 \\
\hline Electrons 'Barrier Height, $\varphi_{e}$ at IOI & & 1.58 \\
\hline Life-time of excited state, $\mathrm{ns}$ & & 2.88 \\
\hline$\Delta \mathbf{E A}=\mathbf{E A}_{\mathrm{CdS}}-\mathbf{E A}_{\text {Org. }}, \mathrm{eV}$ & 1.33 & \\
\hline
\end{tabular}

Calculated from $\varphi_{h}=$ Organic IP $-\Phi$ (metal oxide).

$$
\begin{aligned}
& {\left[\mathrm{Fe}(\mathrm{CN})_{6}\right]^{3-}+h v+(e / h)} \\
& =\left[\mathrm{Fe}(\mathrm{CN})_{6}\right]^{4-}+h(+v e \text { center })
\end{aligned}
$$

where $(e / h)$ is excited SC, however, production of $\mathrm{H}_{2}$ in presence of SC particles can also be possible by a different route. The $\mathrm{H}_{2} \mathrm{PO}_{4}^{-}$it acts as a hole scavenger [29] and the following reaction can take place:

$$
\mathrm{H}_{2} \mathrm{PO}_{4}^{-}+h(\text { from } V B)=\mathrm{H}_{2} \mathrm{PO}_{4}^{*}
$$

The adsorbed $\left[\mathrm{Fe}(\mathrm{CN})_{6}\right]^{3-}$ on the particle

$$
\begin{aligned}
& {\left[\mathrm{Fe}(\mathrm{CN})_{6}\right]_{\mathrm{ads}}^{3-}+(e \text { from } V B)+\mathrm{H}_{3} \mathrm{O}^{+}} \\
& =\left[\mathrm{Fe}(\mathrm{CN})_{6}\right]^{3-}+1 / 2 \mathrm{H}_{2}
\end{aligned}
$$

In the presence of SC, the recorded collector electrode reduction current will be less than that recorded in suspension free $\left.10 \mathrm{mM} \mathrm{Fe}(\mathrm{CN})_{6}\right]^{4-}$ (from now on it will be call reference system). This decrease is due to either reaction 6 or 7 or both. Reaction 6 causes photo-reduction of $\left.\mathrm{Fe}(\mathrm{CN})_{6}\right]^{3-}$, so less of it be reduced electrochemically at the collector electrode. On the other hand the adsorption of $\left.\mathrm{Fe}(\mathrm{CN})_{6}\right]^{4-}$ on the particle surface, reduces the amount of $\left.\mathrm{Fe}(\mathrm{CN})_{6}\right]^{3-}$ produced by reaction 4 , and consequently less electrochemical reduction current will be recorded for collector electrode.

The photo-reduction of $\left.\mathrm{Fe}(\mathrm{CN})_{6}\right]^{3-}$ caused by $\mathrm{SC}$ is calculated as follows:

Photoreduction current;

$$
\begin{aligned}
I_{\text {photored }}= & \text { Ired in reference system } \\
& -I_{\text {red }} \text { in presence of SC }
\end{aligned}
$$

The greater the $\mathrm{I}_{\text {photored, }}$ the better the $\mathrm{SC}$ is for the photolysis process.

\subsubsection{Photolysis of the Suspension}

Aqueous suspensions of pure and surface modified CdS in $0.2 \mathrm{M}$ phosphate buffer at $\mathrm{pH} 6$ containing $0.02 \mathrm{M}$ of $\mathrm{K}_{4}\left[\mathrm{Fe}(\mathrm{CN})_{6}\right]$ were subject to the photolysis process. The potential of the Pt collector electrode was kept constant at $0.000 \mathrm{~V}$ vs $\mathrm{Ag} / \mathrm{AgCl}$. The results are displayed in Figures 3 and 4. The recorded photocurrent in these figures is due to electrochemical reduction of $\mathrm{K}_{3}\left[\mathrm{Fe}(\mathrm{CN})_{6}\right]$. In the presence of illuminated native or surface modified $\mathrm{CdS}$, reduction of $\mathrm{K}_{3}\left[\mathrm{Fe}(\mathrm{CN})_{6}\right]$ can take place by an electrochemical and/or by a photochemical process, but the collector electrode records only the electrochemical process. Figure 3 shows that the recorded electrochemical-reduction current in homogeneous solutions of $\mathrm{K}_{4}\left[\mathrm{Fe}(\mathrm{CN})_{6}\right]$ is greater than that recorded for heterogeneous solutions in the presence of native $\mathrm{CdS}$ (Figure 3(c)) and of CdS/PTTh (Figure 3(b)). This also indicates that photo-reduction in the presence of the native $\mathrm{CdS}$ is greater than that for the $\mathrm{CdS} / \mathrm{PTTh}$ systems.

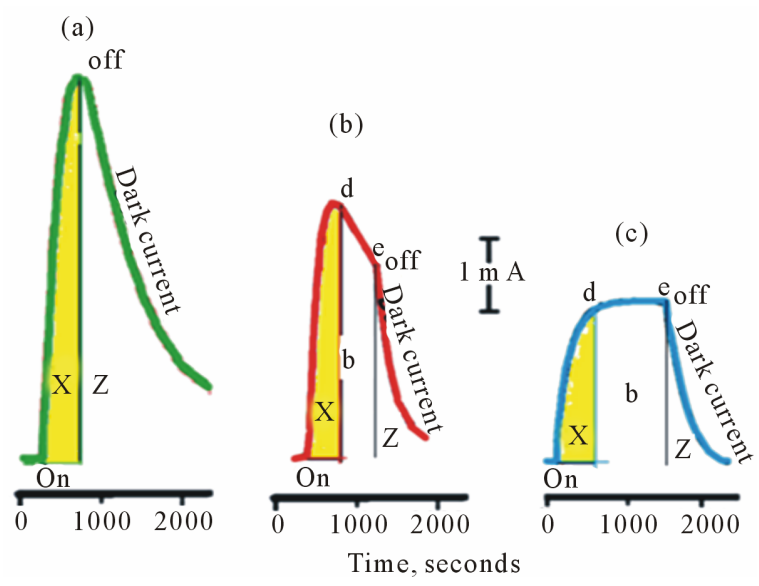

Figure 3. Photolysis of aqueous suspensions of studies IOI containing $0.2 \mathrm{M}$ Phosphate buffers and $10 \mathrm{mM}$ of $\left[\mathrm{Fe}(\mathrm{CN})_{6}\right]^{4-}$ (a) Ref. (10 mM of $\left.\left[\mathrm{Fe}(\mathrm{CN})_{6}\right]^{4-}\right)$; (b) Ref. + CdS/PTTh; (c) Ref. + CdS.
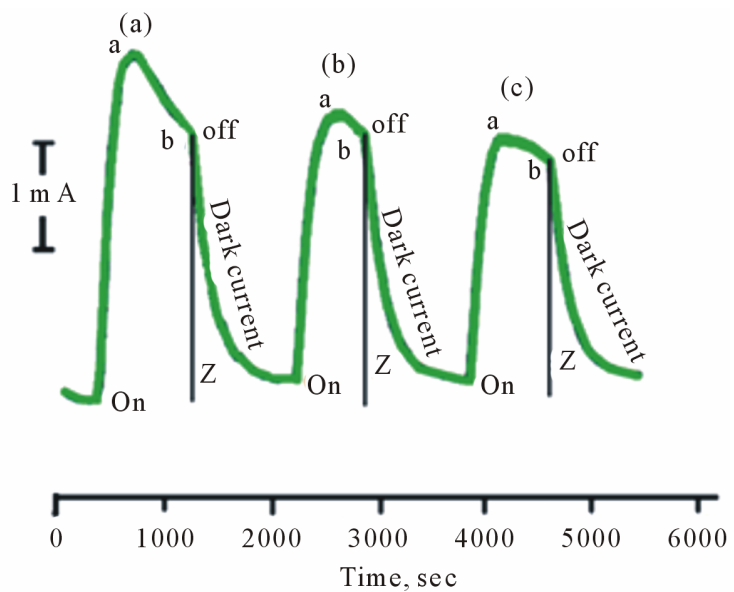

Figure 4. Photolysis of aqueous suspensions of $\mathrm{CdS} / \mathrm{PTTh}$ containing $0.2 \mathrm{M}$ Phosphate buffers and $10 \mathrm{mM}$ of $\left[\mathrm{Fe}(\mathrm{CN})_{6}\right]^{4-}((\mathrm{a}),(\mathrm{b}),(\mathrm{c})$ are cycles of photolysis $)$. 
The smaller electrochemical-reduction current in the heterogeneous system than that in homogenous system can be explained as follows. When oxide nanoparticles are added to $\left[\mathrm{Fe}(\mathrm{CN})_{6}\right]^{4-}$ solutions, the following processes took place:

$$
\begin{aligned}
& \mathrm{M}^{+Z}(\text { solubility equilibrium })+\left[\mathrm{Fe}(\mathrm{CN})_{6}\right]^{4-} \\
= & M\left\{\left[\mathrm{Fe}(\mathrm{CN})_{6}\right]^{4-Z}\right\}_{(\mathrm{s})} \\
M & \left\{\left[\mathrm{Fe}(\mathrm{CN})_{6}\right]^{4-Z}\right\}_{(\mathrm{s})} \text { will stabilize }[30,31] \text { the sur- }
\end{aligned}
$$

face against photo-degradation. Calculations based on particle size (100-nm radius), CdS, and the stoichiometry of reaction 5 indicated that the amount of $\left[\mathrm{Fe}(\mathrm{CN})_{6}\right]^{4-}$ consumed in reaction 5 is less that $0.06 \%$ of its the original concentration of $20.0 \mathrm{mM} / \mathrm{L}$.

2) Adsorption of $\left[\mathrm{Fe}(\mathrm{CN})_{6}\right]^{3-}$ (product of reaction 1) on the surface of nanoparticles [32-34].

Adsorption decreases the amount of $\left[\mathrm{Fe}(\mathrm{CN})_{6}\right]^{4-}$ oxidized in reaction 1 , while adsorption of $\left[\mathrm{Fe}(\mathrm{CN})_{6}\right]^{3-}$ reduces the amount of free $\left[\mathrm{Fe}(\mathrm{CN})_{6}\right]^{3-}$ that can reach the $\mathrm{Pt}$ regenerator electrode. In both cases the recorded reduction current will be less than that reported in homogenous system. However, under illumination all of $\left[\mathrm{Fe}(\mathrm{CN})_{6}\right]^{4-}$ will be oxidized to $\left[\mathrm{Fe}(\mathrm{CN})_{6}\right]^{3-}$ and the surface of nanoparticles will be covered only with $\left[\mathrm{Fe}(\mathrm{CN})_{6}\right]^{3-}$. This amount of $\left[\mathrm{Fe}(\mathrm{CN})_{6}\right]^{3-}$ will be identified from now on as $\left\{\left[\mathrm{Fe}(\mathrm{CN})_{6}\right]^{3-}\right\}_{\text {ads }}$. This adsorbed ferricyanide will be photochemically reduced at the nanoparticle surface. The very small amount of

$\left[\mathrm{Fe}(\mathrm{CN})_{6}\right]^{4-}$ consumed in making the insoluble layer $(<0.05 \%)$ suggests that adsorption phenomena are the main factors that can explain why the reduction current recorded by $\mathrm{Pt}$ regenerator electrode in the presence of nanoparticles is lower than that in homogenous solution. The relatively high concentration of $\mathrm{H}_{2} \mathrm{PO}_{4}^{1-}(0.2 \mathrm{M})$ in comparison with $0.02 \mathrm{M}$ concentration of $\left[\mathrm{Fe}(\mathrm{CN})_{6}\right]^{4-}$ causes $\mathrm{H}_{2} \mathrm{PO}_{4}^{1-}$ to be the major adsorbed species on the surface of nanoparticles. The following mechanism is suggested for the photochemical reduction that causes the reversibility of reaction 1 :

Step $1\left[\mathrm{Fe}(\mathrm{CN})_{6}\right]^{4-}+h v=\left[\mathrm{Fe}(\mathrm{CN})_{6}\right]^{3-}+e_{a q-}$

Step 2

$\left[\mathrm{Fe}(\mathrm{CN})_{6}\right]^{3-}+\mathrm{SC}$ nanoparticles $\rightarrow\left\{\left[\mathrm{Fe}(\mathrm{CN})_{6}\right]^{3-}\right\}_{\text {ads }}$

Step $3 \mathrm{H}_{2} \mathrm{PO}_{4}^{1-}$ acts as hole scavenger and undergoes photo-oxidation to $\mathrm{H}_{2} \mathrm{PO}_{4}^{*}$ [29] as follows:

$$
\mathrm{SC}(e / h)+\mathrm{H}_{2} \mathrm{PO}_{4}^{1-}=\mathrm{H}_{2} \mathrm{PO}_{4}^{*}+e \text { (conduction band) }
$$

where $(e)$ electrons in conduction band, $h=$ hole in valence band (Figure 5). This step is based on the fact that the calculated hole barrier heights [35] for the SCs used in this study is $0.9 \mathrm{eV}$ and much smaller than e barrier heights $(1.68 \mathrm{eV})$. These suggests that the hole transfer is to take place first either to oxidize $\mathrm{H}_{2} \mathrm{PO}_{4}^{1-}$ (because of its higher concentration than Ferrocyanide anion), or to undergoes electron injection from the excited state of PTTh. By either mechanism the hole isneutralized first, suggests that reduction of Ferricyanide follow the hole consummation as Step 4 shows:

Step 4

$\left\{\left[\mathrm{Fe}(\mathrm{CN})_{6}\right]^{3-}\right\}_{\mathrm{ads}}+\mathrm{e}($ from $\mathrm{CB})=\left\{\left[\mathrm{Fe}(\mathrm{CN})_{6}\right]^{4-}\right\}_{\mathrm{ads}}$.

Step $5\left\{\left[\mathrm{Fe}(\mathrm{CN})_{6}\right]^{4-}\right\}_{\text {ads }}$ desorbed to give free $\left\{\left[\mathrm{Fe}(\mathrm{CN})_{6}\right]^{4-}\right\}_{\text {desorb }}$.

Step $6\left\{\left[\mathrm{Fe}(\mathrm{CN})_{6}\right]^{4-}\right\}_{\text {desorb }}$ photo-oxidized in the homogenous solution to $\left[\mathrm{Fe}(\mathrm{CN})_{6}\right]^{3-}$ and included in repeating Step 1.

The portion of $\left[\mathrm{Fe}(\mathrm{CN})_{6}\right]^{3-}$ generated by Step 1 and not adsorbed in Step 2 reaches the Pt electrode to be re-
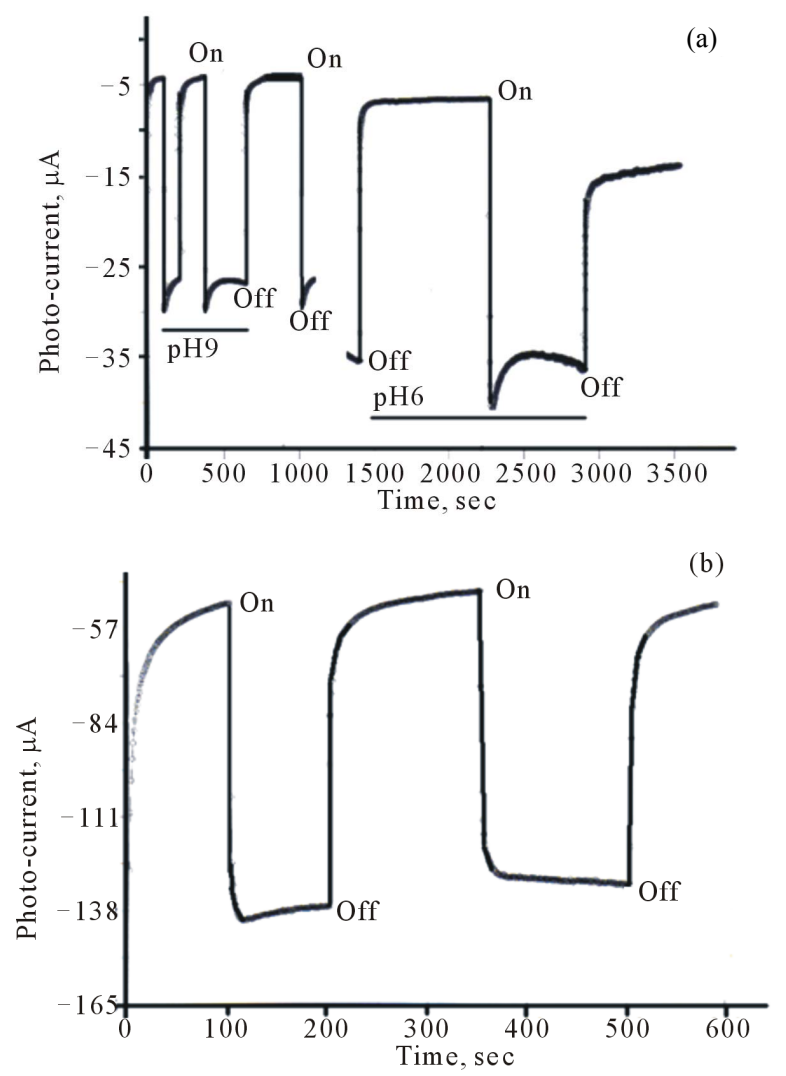

Figure 5. (a) Current-time plot for thin film of CdS/PTTh on FTO at $0.400 \mathrm{~V}$ vs $\mathrm{Ag} / \mathrm{AgCl}$ in $0.2 \mathrm{M}$ Phosphate buffers and $10 \mathrm{mM}$ of $\left[\mathrm{Fe}(\mathrm{CN})_{6}\right]^{4-}$ at different pHs; (b) Currenttime plot for thin film of CdS/PTTh on FTO at $400 \mathrm{~V}$ vs $\mathrm{Ag} / \mathrm{AgCl}$ in $0.2 \mathrm{M}$ Phosphate buffers and $10 \mathrm{mM}$ of $\left[\mathrm{Fe}(\mathrm{CN})_{6}\right]^{4-}$ at $\mathrm{pH} 8.82$. 
duced back is represented by areas $X$ in Figure 3. The difference in area $X$ in Figure 3(a) and that in Figures 3(b) and (c) represent the amount of adsorbed

$\left.\mathrm{Fe}(\mathrm{CN})_{6}\right]^{3-}$ on the $\mathrm{CdS} / \mathrm{PTTh}(\mathbf{3}(\mathbf{b}))$ or $\mathrm{CdS}(\mathbf{3}(\mathbf{C}))$ nanoparticle surfaces. It can be concluded that areas $\mathrm{X}$ in Figures 3 directly reflect the behavior of $\mathrm{Pt}$ generator electrode in the absence of SC interference.

\subsection{Dark Current}

The behavior of the Pt regenerator electrode in the absence of light can be explained by investigation of sections $(\mathbf{Z})$ in Figures $\mathbf{3}$ and $\mathbf{4}$ which represents electrochemical reduction current in the absence of light (dark current). In both homogenous and heterogeneous systems studied in this work, the electrochemical reduction currents are supposed to instantaneously drop to zero upon stopping the illumination. However this drop was not observed as Figure 3 illustrates. The reported electrochemical reduction current in the dark for the homogeneous and heterogeneous phases (areas Z) of the system can be attributed to the radial diffusion of $\left[\mathrm{Fe}(\mathrm{CN})_{6}\right]^{3-}$ in the cylindrical zone of the Pt regenerator electrode. The shape of the working electrode disrupts the continuity of the stirring effects. This makes the diffusion within the cylindrical shape an important factor for the reduction current.

\subsection{Electrochemical Behavior of Pt Electrode in Presence of CdS/PTTh Nanoparticles}

Areas b, in Figures 3(b) and (c), or the plateaus in Figure 4(b) and (c) are the representation of the outcome of steps 2-6 of the above mechanism, and reflect the behavior of the Pt regenerator electrode in the presence of SC nanoparticles, and also explain how the SC nanoparticles made the reversibility of reaction 1 possible. It is worth noticing that:

1) Reduction current reported by Pt electrode in presence of CdS/PTTH (Figure 3(b)) is greater than that in the presence of CdS only (Figure 3(c)). This means that the amount of $\left[\mathrm{Fe}(\mathrm{CN})_{6}\right]^{3-}$ reaches Pt electrode is greater in presence of $\mathrm{CdS} / \mathrm{PTTh}$ than that in presence of $\mathrm{CdS}$. Two factors explain this observation: first, due to the layer of PTTh on the surface of the CdS, formation of $\mathrm{KCd}\left[\mathrm{Fe}(\mathrm{CN})_{6}\right]$ will not take place, and second , the $\mathrm{CdS} /$ PTTh withhold (by adsorption) an amount of $\left[\mathrm{Fe}(\mathrm{CN})_{6}\right]^{3-}$ less than CdS.

2) The decrease of the reduction current recorded by the Pt electrode in presence of $\mathrm{CdS} / \mathrm{PTTh}$ as represented by the line de (Figure 3(b)).

3) The steady constant reduction current recorded by the Pt electrode in presence of CdS only as represented by the line de (Figure 3(c)).

The observations mentioned in items 2 and 3 above can be interpreted as follow: This decrease in reduction current (Figure 3(b)) can be explained considering partial separation of PTTh from the surface of the CdS nanoparticles during photolysis process. As more of the CdS surfaces are exposed to the solution, more withholding of $\left[\mathrm{Fe}(\mathrm{CN})_{6}\right]^{3-}$ occurs and therefore less reaches Pt electrode to be reduced. The data displayed in Figure 4 shows that the slope of line ab in Figure 4 decreases from cycle (a) to cycle (c), coupled with the fact that the current at point $b$ is decreasing going from cycle (a) to cycle (c), supports our assumption that the modifier PTTh at the interface is gradually separated from the IOI assembly. In cycle (c), CdS/PTTh systems produces steady state current similar to that observed by native CdS (Figure 3(c)).

The fact that the line ab in Figure 4(c) is almost horizontal suggests that the formation of a layer of $\mathrm{Cd}_{\mathrm{x}}\left[\mathrm{Fe}(\mathrm{CN})_{6}\right]_{\mathrm{y}}$ on $\mathrm{CdS}$ surface [20] stabilizes the surface and enhances the adsorption of $\left[\mathrm{Fe}(\mathrm{CN})_{6}\right]^{3-}$. The steady, constant reduction current at the plateau (Figure 3(c)) also reflects an efficient reversible adsorption/desorption $[30,34]$ process at the SC nanoparticle surfaces.

\subsection{Photoelectrochemical Behavior of CdS/PTTh in Thin Solid Film Assembly}

Cyclic voltammograms (CVs) of CdS/PTTh thin solid films loaded over ITO electrodes in dark and under illumination are displayed in Figure 6. They indicate that the electrode was photoactive with the $\left[\mathrm{Fe}(\mathrm{CN})_{6}\right]^{4-13-}$ redox system. The observed photocurrent within the studied potential ranges indicates that $\left[\mathrm{Fe}(\mathrm{CN})_{6}\right]^{4-}$ is immobilized in the IOI assembly and underwent electron accepting/donating processes. Such immobilization caused

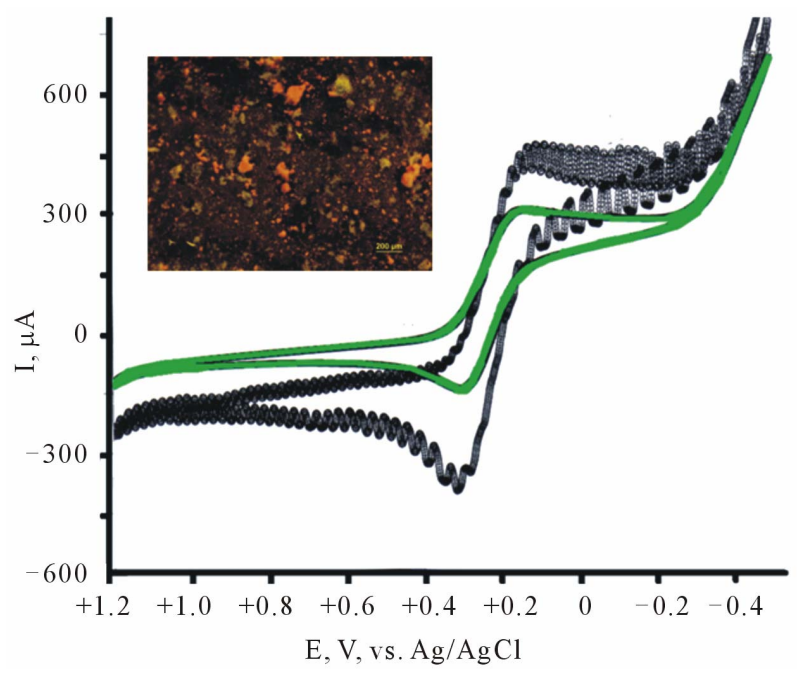

Figure 6. CV (dark and under illumination) of Thin film of CdS/PTTh on FTO in $0.2 \mathrm{M}$ Phosphate buffers and $10 \mathrm{mM}$ of $\left[\mathrm{Fe}(\mathrm{CN})_{6}\right]^{4-}$ (inset is microscopic image of $\mathrm{CdS} / \mathrm{PTTh}$ thin solid film. 
Table 2. Photolysis of $\left.10 \mathrm{mMFe}(\mathrm{CN})_{6}\right]^{4-}$ containing particles of studied SC' suspensions in $0.2 \mathrm{M}$ phosphate buffer, pH 6.

\begin{tabular}{|c|c|c|c|c|c|}
\hline System & $\begin{array}{c}\text { Photon due to free } \\
{\left[\mathrm{Fe}(\mathrm{CN})_{6}\right]^{4-\mathrm{e}}}\end{array}$ & $\begin{array}{l}\text { Adsorbed d } \\
\left.\mathrm{Fe}(\mathrm{CN})_{6}\right]^{3-}\end{array}$ & $\%$ adsorbed & $\begin{array}{c}1000 \text { s photolysis } \\
\text { of suspensions }\end{array}$ & Rate of IOI decay \\
\hline Ref. System ${ }^{a}$ & $0.495 \mathrm{C}$ & & & & \\
\hline $\mathrm{CdS}+\mathrm{Ref}$ & $0.252 \mathrm{C}$ & $0.243 \mathrm{C}$ & 49.1 & $0.661 \mathrm{C}$ & \\
\hline $\begin{array}{l}\text { (CdS/PTTh) } \\
\quad+\text { Ref. }\end{array}$ & $0.350 \mathrm{C}$ & $0.145 \mathrm{C}$ & 29.3 & $0.705 \mathrm{C}$ & $4.1 \times 10^{-5} \mathrm{C} / \mathrm{s}$ \\
\hline
\end{tabular}

${ }^{\mathrm{a}}$ Ref. $=10 \mathrm{mM}\left[\mathrm{Fe}(\mathrm{CN})_{6}\right]^{4-}$ in $0.2 \mathrm{M}$ Phosphate buffer; ${ }^{\mathrm{b}}$ Calculated as follow: photons (ref.) - photons in suspension system; ${ }^{\mathrm{c}}$ Integrated area/s $\mathrm{X}$ in Figure 3 .

an adjustment of the flat band potential to accommodate these processes.

The photoelectrochemical response of a thin solid film of an FTO electrode modified with CdS/PTTh in $0.2 \mathrm{M}$ phosphate containing $10 \mathrm{mM}\left[\mathrm{Fe}(\mathrm{CN})_{6}\right]^{4-}$ under a constant potential of $0.40 \mathrm{~V}$ vs $\mathrm{Ag} / \mathrm{AgCl}$ electrode is displayed in Figure 5(a). It can be noticed that the photoactivity of the film is greater at $\mathrm{pH} 6$ than at $\mathrm{pH} 9$. Furthermore, thin films did not show the phenomena of dark current observed with suspensions, evident by the sharp drop in the photocurrent under dark. The effect of $\mathrm{pH}$ on the photoactivity of this thin solid film assembly can be attributed to the fact that $\mathrm{pH}$ changes alter the position of the CB (conduction band) and VB (valance band) of the IOI assembly. On the other hand the results displayed in Figure 5(b) show that the photoelectron-chemical response of the same assembly in $0.2 \mathrm{M}$ acetate buffer $(\mathrm{pH}$ 8.82) containing $10 \mathrm{mM}\left[\mathrm{Fe}(\mathrm{CN})^{6}\right]^{4-}$ at $0.40 \mathrm{~V}$ vs $\mathrm{Ag} /$ $\mathrm{AgCl}$ is greater with steady state current for the longer period of time than that recorded in phosphate buffer. This greater response can be attributed to oxidation of acetate under illumination conditions.

\section{Conclusion}

The results obtained in this study represent our attempt to establish a data base regarding the photo-electrochemical behavior of a CdS/PTTh IOI assembly. The charge injections within this IOI interface and from/to the redox systems in contact with these assemblies are controlled by four factors: conduction and valence band of the inorganic semiconductor; higher unoccupied/lower occupied molecular orbital (HUMO/LOMO) of the organic semiconductor; the life-time of the excited state of each semiconductor; and the amount of overlapping between the band gaps of these two systems. The recorded photoelectrochemical behavior of CdS/PTTh in both suspension and thin solid forms indicated that PTTh may reduce the activities of the surface states on native $\mathrm{CdS}$, giving less photocurrent than native $\mathrm{CdS}$. While the life time of $\mathrm{CdS}$ nanoparticles (0.1 to $1.07 \mathrm{~ns})$ depends on their size [36], it is still shorter than that of PTTh. This allows a charge exchange between CdS and PTTh. The charge transfer at IOI illuminated interface is controlled by the relative barrier heights of electrons and of holes. The mechanism of charge transfer can propagate via hole transfer if the hole barrier height is very small compare with that of an electron. The electron donor nature of PTTh relative to $\mathrm{CdS}$ with low hole barrier height (Table 2) suggests that charge transfer with IOI is dictated by the hole transfer. The fact that the band gap of both PTTh and CdS are of the similar magnitude, suggests that both $\mathrm{CdS}$ and PTTh are simultaneously active under illumination. The more efficient light harvesting of PTTh in inorganic semiconductors when compared to other IOI was attributed to its broader absorption spectrum and more efficient electron hopping [37]. Modifying the surface of CdS tangibly changes the value of the flat band potential $\left(\mathrm{E}_{\mathrm{fb}}\right)$. The reported value of $\mathrm{E}_{\mathrm{fb}}$ for $\mathrm{CdS} / \mathrm{PTTh}$ at $0.2 \mathrm{~V}$ vs $\mathrm{Ag} / \mathrm{AgCl}$ is more positive than that reported for native $\mathrm{CdS}$ in aqueous solution [21]. This alters the interface dipole barriers at the IOI and directly affects the adsorption of $\left[\mathrm{Fe}(\mathrm{CN})_{6}\right]^{3-}$ process at this interface.

\section{REFERENCES}

[1] W. Chen, S. Chen, S. Chen, Y. L. Huang, H. Huang, D. C. Qi, X. Y. Gao, J. Ma and A. T. S. Wee, "OrientationControlled Charge Transfer at $\mathrm{CuPc} / \mathrm{F}_{16} \mathrm{CuPc}$ Interfaces," Journal of Applied Physics, Vol. 106, No. 6, 2009, Article ID: 064910. doi:10.1063/1.3225918

[2] T. R Heera and L. Cindrella, "PbS/CoS-Pani Composite Semiconductor Films," Materials Science in Semiconductor Processing, Vol. 14, No. 2, 2011, pp. 151-156. doi:10.1016/j.mssp.2011.02.002

[3] S. Suresh, A. Pandikumar, S. Murugesan, R. Ramaraj, Samuel Paul Raj, Photovoltaic performance of solid-state solar cells based on $\mathrm{ZnO}$ nanosheets sensitized with low-cost metal-free organic dye, Solar Energy 85, 2011, pp. 1787-1793.

[4] M. Hahlin, E. M. Johansson, S. Plogmaker, M. Odelius, P. D. Hagberg, L. Sun, H. Siegbahn and H. Rensmo, "Electronic and Molecular Structures of Organic Dye/ $\mathrm{TiO}_{2}$ Interfaces for Solar Cell Applications: A Core Level Photoelectron Spectroscopy Study," Physical Chemistry Chemical Physics, Vol. 12, No. 7, 2010, pp. 1507-1509. doi:10.1039/b913548k

[5] D. Cheyns, K. Vasseur, C. Rolin, J. Genoe, J. Poortmans and P. Heremans, "Nanoimprinted Semiconducting Polymer Films with $50 \mathrm{~nm}$ Features and Their Application to Organic Heterojunction Solar Cells," Nanotechnology, Vol. 19, No. 42, 2008, Article ID: 424016. 
doi:10.1088/0957-4484/19/42/424016

[6] S. Blumstengel, N. Koch, S. Sadofev, P. Schafer, H. R. Johnson, J. P. Rabe and F. Henneberger, "Room Temperature Ferromagnetism in ZnO Films Due to Defects," Applied Physics Letters, Vol. 92, No. 19, 2008, Article ID: 193303. doi:10.1063/1.2918089

[7] D. Adams, "Charge Transfer on the Nanoscale: Current Status," Journal of Physical Chemistry B, Vol. 107, No. 28, 2003, pp. 6668-6674. doi:10.1021/jp0268462

[8] K. G. Thomas and P. V. Kamat, "Chromophore-Functionalized Gold Nanoparticles," Accounts of Chemical Research, Vol. 36, No. 12, 2003, pp. 888-898. doi:10.1021/ar030030h

[9] P. V. Kamat, "Photophysical, Photochemical and Photocatalytic Aspects of Metal Nanoparticles," Journal of Physical Chemistry B, Vol. 106, No. 32, 2002, pp. 77297244. doi:10.1021/jp0209289

[10] X. L. Hu, G. S. Li and J. C. Yu, "Design, Fabrication and Modification of Nanostructured Semiconductor Materials for Environmental and Energy Applications," Langmuir, Vol. 26, No. 5, 2010, pp. 3031-3039. doi:10.1021/la902142b

[11] K. Kasem, S. Menges and S. Jones, "Photoelectrochemical Studies of Poly[1-(2-aminophenya)pyrrole]," Canadian Journal of Chemistry, Vol. 87, 2009, pp. 1-8.

[12] Q. Zhang, T. Wu, X. H. Bu, T. Tran and P. Feng, "Ion Pair Charge-Transfer Salts Based on Metal Chalcogenide Clusters and Methyl Viologen Cations," Chemistry of Materials, Vol. 20, No. 13, 2008, pp. 4170-4172.

[13] M. Graetzel, "Photoelectrochemical Cells," Nature, Vol. 414, 2001, pp. 338-342.

[14] K. Kasem and C. Davis, "Photoelectrochemical Studies on Colloidal Copper(I) Oxide/Modified with Some Organic Semiconductors: Incentive for Use of Nanoparticle System," Bulletin of Materials Science, Vol. 31, No. 7, 2008, pp. 925-929. doi:10.1007/s12034-008-0147-5

[15] S. Kohtani, A. Kudo and T. Sakata, "Pectral Sensitization of a Titania Semiconductor Electrode by Cadmium Sulfide Microcrystals and Its Photoelectrochemical Properties," Chemical Physics Letters, Vol. 206, No. 1-4, 1993, pp. 166-170. doi:10.1016/0009-2614(93)85535-V

[16] R. Vogel, P. Hoyer and H. Weller, "Quantum-Sized PbS, $\mathrm{CdS}, \mathrm{Ag}_{2} \mathrm{~S}, \mathrm{Sb}_{2} \mathrm{~S}_{3}$, and $\mathrm{Bi}_{2} \mathrm{~S}_{3}$ Particles as Sensitizers for Various Wide-Bandgap Semiconductors," Journal of Physical Chemistry, Vol. 98, No. 12, 1994, pp. 31833187. doi:10.1021/j100063a022

[17] R. Plass, S. Pelet, J. Krueger, M. Gratzel and U. Bach, "Quantum Dot Sensitization of Organic-Inorganic Hybrid Solar Cells," Journal of Physical Chemistry B, Vol. 106, No. 31, 2002, pp. 7578-7580. doi:10.1021/jp0204531

[18] L. Peter, K. Wijayantha, D. Riley and J. Waggett, "BandEdge Tuning in Self-Assembled Layers of $\mathrm{Bi}_{2} \mathrm{~S}_{3}$ Nanoparticles Used to Photosensitize Nanocrystalline $\mathrm{TiO}_{2}$," Journal of Physical Chemistry B, Vol. 107, No. 33, 2003, pp. 8378-8381. doi:10.1021/jp0303341

[19] K. Kasem, "Photo-Electrochemical Studies on Aqueous Suspensions of 3-Dodecyl 2-5 Di-ThionylPyrrole/Metal
Oxide Photoactive Interface," Surface and Interface and Analysis, Vol. 43, No. 12, 2011, pp. 1527-1532. doi:10.1002/sia.3747

[20] K. K. Kasem, "Photoelectrochemical Studies on Stationary surface Modified CdSe Electrodes," Materials Science and Engineering: B, Vol. 65, No. 2, 1999, pp. 127 134. doi:10.1016/S0921-5107(99)00218-4

[21] K. K. Kasem, "Photo-Electrochemistry at Polymer/Semiconductor Interface. Characterization of Surface Modified CdS Based Photovoltaic Cells," Journal of Materials Science, Vol. 34, No. 21, 1999, pp. 5237-5342. doi:10.1023/A:1004772231981

[22] H. Michikazu, K. Takeshi, K. Mutsuko, I. Sigeru, S. Kiyoaki, T. Akira, N. K. Junko and K. Kazunari, " $\mathrm{Cu}_{2} \mathrm{O}$ as a Photocatalyst for Overall Water Splitting under Visible Light Irradiation," Chemical Communications, No. 3, 1998, pp. 357-358.

[23] A. Tatarets, I. A. Fedyunyayeva, T. S. Dyubko, Y. A. Povrozin, A. O. Doroshenko, E. Terpetschnig and L. D. Patsenker, "Synthesis of Water-Soluble, Ring-Substituted Squaraine Dyes and Their Evaluation as Fluorescent Probes and Labels," Analytica Chimica Acta, Vol. 214, 2006, pp. 570-576.

[24] R. A. de Barros, M. C. C. Areias and W. M. de Azevedo, "Conducting Polymer Photopolymerization Mechanism," Synthetic Metal, Vol. 160, No. 1-2, 2010, pp. 61-64. doi:10.1016/j.synthmet.2009.09.033

[25] Z. H. Han, H. Y. Zhu, S. R. Bulcock and S. P. Ringer, "One-Step Synthesis and Structural Features of CdS/ Montmorillonite Nanocomposites," Journal of Physical Chemistry B, Vol. 109, No. 7, 2005, pp. 2673-2678. doi:10.1021/jp046541i

[26] D. N. McIlroy, J. Zhang, P. A. Dowben and D. Heskett, "Band Gaps of Doped and Undoped Films of Molecular Icosahedra," Materials Science and Engineering: A, Vol. 217-218, 1996, pp. 64-68.

[27] K. Kasem and M. Dahn, "Photodissociation of Water Using Colloidal Nanoparticles of Doped Titanium(IV) Oxide Semiconductors for Hydrogen Production," Current Science, Vol. 99, No. 8, 2010, pp. 1087-1092.

[28] L. S. Roman, I. A. Hummelgen, F. C. Nart, F. C. Peres and E. I. de Sa, "Determination of Electroaffinity and Ionization Potential of Conjugated Polymers via FowlerNordheim Tunneling Measurements: Theoretical Formulation and Application to Poly(p-phenylenevinylene," Journal of Chemical Physics, Vol. 105, No. 23, 1998, pp. 10614-10620. doi:10.1063/1.472947

[29] A. Mohammad, G. K. C. Low and R. W. Matthews, "Effects of Common Inorganic Anions on Rates of Photocatalytic Oxidation of Organic Carbon over Illuminated Titanium Dioxide," Journal of Physical Chemistry, Vol. 94, No. 17, 1990, pp. 6820-6825. doi:10.1021/j100380a051

[30] H. Rubin, D. Arent, B. Humphrey and A. Bocarsly, "Overlayer Formation as a Source of Stability in the N-Type Photoelectrochemical Cell," Journal of Electrochemical Society, Vol. 134, No. 1, 1987, pp. 93-101. doi:10.1149/1.2100444 
[31] K. Tennakone, "The Activation of N-Type Semiconduction in Ferrocyanides and p-Type Semiconduction in Ferricyanides by Interstitial Water," Journal of Physical C: Solid State Physics, Vol. 16, No. 34, 1983, p. L1193. doi:10.1088/0022-3719/16/34/001

[32] J. Desilvestro, S. Bons, E. Vrachnqu and M. Gratzel, "Electrochemical and FTIR Spectroscopic Characterization of Ferrocyanide-Modified $\mathrm{TiO}_{2}$ Electrodes Designed for Efficient Photosensitization," Journal of Electroanalytical Chemistry, Vol. 234, No. 2, 1988, pp. 411-422.

[33] W. P. Cheng, C. Huang and Y. C. Chien, "Competitive Adsorption of Ferricyanide and Ferrocyanide On $\gamma-\mathrm{Al}_{2} \mathrm{O}_{3}$ Surface," Journal of Colloid \& Interface Science, Vol. 224, No. 2, 2000, pp. 291-296. doi:10.1006/jcis. 1999.6684

[34] C. M. Pharr and P. R. Griffiths, "Infrared Spectroelectrochemical Analysis of Adsorbed Hexacyanoferrate Species Formedduring Potential Cycling in the Ferrocyanide/Ferricyanide Redox Couple," Analytical Chemistry, Vol. 69, No. 22, 1997, pp. 4673-4679. doi:10.1021/ac9611201
[35] T. Lana Villarreal, R. Gómez, M. Neumann-Spallart, N. Alonso-Vante and P. Salvador, "Semiconductor Photooxidation of Pollutants Dissolved in Water: A Kinetic Model for Distinguishing between Direct and Indirect Interfacial Hole Transfer. I. Photoelectrochemical Experiments with Polycrystalline Anatase Electrodes under Current Doubling and Absence of Recombination," Journal of Physical Chemistry B, Vol. 108, No. 39, 2004, pp. 15172-15181. doi:10.1021/jp049447a

[36] G. H. Ma, S.-H. Tang, W. X. Sun, Z. X. Shen, W. M. Huang and J. L. Shi, "Size-Dependent Excited State Properties of CdS Nanocrystals," Physics Letters A, Vol. 299, No. 5-6, 2002, pp. 581-585. doi:10.1016/S0375-9601(02)00680-1

[37] J. L. Marcos, J. Santos, E. Ferreira, R. R Radovanovic, L. A. Oswaldo and M. G. Emerson, "Enhancement of the Photoelectrochemical Response of Poly(Terthiophenes) by $\mathrm{CdS}(\mathrm{ZnS})$ Core-Shell Nanoparticles," Thin Solid Films, Vol. 517, No. 18, 2009, pp. 5523-5529. doi:10.1016/i.tsf.2009.03.170 